\title{
BLOOD CHEMISTRY PROFILE OF SURUBIM HYBRID FISH (Pseudoplatystoma Reticulatum X P. Corruscans) RAISED IN DIFFERENT STOCKING DENSITIES
}

\author{
Perfil bioquímico do híbrido de Surubim (Pseudoplatystoma reticulatum \\ $X$ P. corruscans) criado em diferentes densidades
}

\author{
Carla Rosa Labarrère ${ }^{1}$, Paulo Mário Carvalho de Faria ${ }^{2}$, \\ Edgar de Alencar Teixeira ${ }^{3}$, Marília Martins Melo ${ }^{4}$
}

\begin{abstract}
Massive production, such as fish growing in water recirculation system, imposes challenges to animals capable of altering their homeostatic balance, and is able to affect their physiological performance. Therefore, the levels of ions and serum enzymes can be used as indicators of fish health. This study aimed to analyze the blood biochemistry profile of hybrid surubim ( $P$. reticulatum $\mathrm{X}$ $P$. corruscans) submitted to different stocking densities in water recirculation system, in two distinct stages of production, from 150 to $400 \mathrm{~g}$ (first trial), and 400 to $1000 \mathrm{~g}$ (second trial). In the first trial, the five stocking rates were: 27.5, 47.5, 67.5, 87.5 and 107.5 fish $/ \mathrm{m}^{3}$ of water. To obtain these densities, it was used 11, 19, 27, 35 and 43 fish per tank, respectively. In the second trial, five stocking rates were: 10, 20, 30, 40 and $50 \mathrm{fish} / \mathrm{m}^{3}$ of water. To obtain these densities we used 4, 8, 12,16 and 20 fish per tank, respectively. The concentrations of glucose, cholesterol, triglycerides, urea, creatinine, alkaline phosphatase (ALP), aspartate aminotransferase (AST), lactate dehydrogenase (LDH), calcium, phosphorus, potassium and magnesium were obtained. Only urea concentrations in first trial and ALP and AST concentrations in second trial were influenced by stocking density, presenting a significant difference between groups. Thus, in both trials the hybrid fish studied maintained homeostasis when reared in different stocking densities.
\end{abstract}

Index terms: Fish, hybrid, plasma biochemistry.

\begin{abstract}
RESUMO
Dentre os sistemas de produção, o de recirculação de água impõe desafios para os animais que podem ser capazes de alterar o seu equilíbrio homeostático, afetando o índice de desempenho. Por conseguinte, os níveis de ions e enzimas séricas podem ser utilizados como indicadores de saúde dos peixes. Neste estudo, objetivo-se analisar o perfil de bioquímico do sangue do híbrido de Surubim ( $P$. reticulatum X $P$. corruscans), submetido a diferentes densidades de estocagem em sistema de recirculação de água, em duas fases distintas de produção, de 150 a $400 \mathrm{~g}$ (primeiro ensaio) e, 400 a $1000 \mathrm{~g}$ (segundo ensaio). No primeiro ensaio, as cinco densidades de estocagem estudadas foram: 27,5, 47,5, 67,5, 87,5 e 107,5 peixes $/ \mathrm{m}^{3}$ de água. Para a obtenção dessas densidades foram utilizados $11,19,27,35$ e 43 peixes por tanque, respectivamente. No segundo ensaio, as cinco densidades de estocagem estudadas foram: 10, 20, 30, 40 e 50 peixes/m3 de água. Para a obtenção dessas densidades foram utilizados 4, 8, 12,16 e 20 peixes por tanque, respectivamente. As concentrações de glicose, colesterol, triglicérides, ureia, creatinina, fosfatase alcalina (FA), aspartato aminotransferase (AST), desidrogenase lática (LDH), cálcio, fósforo, potássio e magnésio foram avaliadas. Apenas as concentrações de ureia no primeiro ensaio e FA e AST no segundo ensaio foram influenciadas pela densidade de estocagem, apresentando uma diferença significativa entre os grupos. Assim, em ambos os ensaios, o Surubim híbrido manteve a homeostase do sangue em diferentes densidades.
\end{abstract}

Termos para indexação: Peixe, híbrido, bioquímica sérica.

(Received in january 21, 2013 and approved in march 03, 2013)

\section{INTRODUCTION}

In aquaculture, the hybridization has been widely used in order to produce animals with better performance than their parental species. Thus, the hybrids are considered commercially viable and, in general, have better growth rate, meat quality, resistance and tolerance to environmental variations. Fishes of the genus Pseudoplatystoma, such as $P$. corruscans (pintado) and $P$. reticulatum (cachara) have been used in large scale among interspecific hybridization programs in Brazil (CARVALHO et al., 2008). These species belong to the family Pimelodidae, an

1 University of Saskatchewan - Canada

'Universidade Federal do Rio Grande do Norte/UFRN - Escola de Agricultura de Jundiaí

3Universidade Federal de Minas Gerais/UFMG - Departmento de Zootecnia - Belo Horizonte - MG - Brasil

${ }^{4}$ Universidade Federal de Minas Gerais/UFMG - Departmento de Veterinária - P.O. Box 567 - Belo Horizonte - MG - Brasil - mariliamm@ufmg.br 
important group of Neotropical Siluriformes with an ample Neotropical distribution, and occur in the Amazon River basin ( $P$. reticulatum), San Francisco River basin $(P$. corruscans) and Prata River basin (P. corruscans and $P$. reticulatum). The "cachapinta" (Pseudoplatystoma corruscans X $P$. reticulatum) is fertile and able to cross and produce post-F1 hybrids (F2 hybrids and backcrosses) in lineage cultivation (PRADO et al., 2012).

Fish raised in intensive farming, as in the production of Surubim in water recirculation system, are submitted to challenges relating to routine practices in fish farming, such as handling, transportation and densification. These practices can alter the homeostatic balance of these animals, affecting energy-dependent processes such as reproduction, growth, and disease resistance (MARCO et al., 2008). Stocking density is widely recognized as a critical husbandry factor in intensive aquaculture because it represents a potential source of chronic stress, which may affect physiology and behavior of farmed fish (ELLIS et al., 2002). It has been demonstrated that rearing at inappropriate stocking densities may impair the growth, reduce immune competence and induce abnormal behavior (BARCELLOS et al., 2004; SCHRAM et al., 2006). For these reasons, research on stocking density is now receiving greater attention in order to come up with future recommendations on stocking density management in relation to the health and welfare of farmed fish (VAN DER NIEUWEGIESSEN et al., 2008).

The levels of serum enzymes and ions can be used as indicators of health for different animal species as well as fish. The evaluation of these blood components may help to determine the influence of stressors on the homeostasis of these animals, and it enables the detection of early conditions that could be affecting the production performance (CNAANI et al., 2004).

In this study, two consecutive experiments were carried out in order to investigate the blood biochemical profile of Pseudoplatystoma spp. to different stocking densities.

\section{MATERIALS AND METHODS}

\section{Raising systems and water quality}

The experiment was conducted in a water recirculation system, a system composed of 20 circular tanks with 400 liters of useful volume, which the water flow was 480 liters per hour per tank. Each one received supplemental aeration tanks. It was used electrical resistance and a thermostat to control and maintain the water at temperatures between $27^{\circ}$ and $29^{\circ} \mathrm{C}$ (LIMA et al., 2006). Dissolved oxygen was analyzed by oximeter (MO$900^{\circledR}$ - Instrutherm) and remained above $4.2 \mathrm{mg} / \mathrm{l}$. The $\mathrm{pH}$ values were observed using $\mathrm{pH}$ meter (Portable $\mathrm{pH}$ Meter $\mathrm{RL} 60 \mathrm{P}^{\circledR}$ - Russel) and were kept at levels between 6.7 and 7.8. Total ammonia and nitrite were measured weekly using a commercial kit (Alfakit). The values did not exceed 0.25 $\mathrm{mg} / \mathrm{l}$ and $0.30 \mathrm{mg} / \mathrm{l}$, respectively. All of these values are acceptable for raising tropical fish (FARIA et al., 2011).

\section{Experimental groups and treatments}

It was used 540 juvenile hybrid surubins (Pseudoplatystoma reticulatum X $P$. corruscans) with initial average weight of $147.6 \pm 2.1 \mathrm{~g}$. The fish stayed in the experiment until they reached a weight close to $400 \mathrm{~g}$. The time required to reach this weight was 67 days. The animals were fed daily ad libitum at $7 \mathrm{am}$ and $6 \mathrm{pm}$ with an extruded commercial diet, $4.0 \mathrm{~mm}$ in diameter and $40 \%$ crude protein. The hybrids were divided into five different treatment groups of which the former and the latter had the lowest and the highest density of storage, respectively. Each treatment was replicated four times, reaching a total of 20 tanks. The five stocking rates were: $27.5,47.5,67.5$, 87.5 and $107.5 \mathrm{fish} / \mathrm{m}^{3}$ of water (TURRA et al. 2009). To obtain these densities, it was used 11, 19, 27, 35 and 43 fish per tank, respectively. The biomass of the animals in the tanks at the beginning of the experiment corresponded to 1623.1, 2776.4, 3981.6, 5228.7 and $6336.3 \mathrm{~g}$, respectively.

Second trial: It was used 240 hybrid surubins (Pseudoplatystoma reticulatum $\mathrm{X} P$. corruscans) with initial average weight of $400.0 \pm 1.4 \mathrm{~g}$ remaining in the experiment until they reached a weight close to $1000 \mathrm{~g}$. The experimental period lasted 72 days. The animals were fed daily ad libitum at $7 \mathrm{am}$ and $6 \mathrm{pm}$ with an extruded commercial diet, $8.0 \mathrm{~mm}$ in diameter and $40 \%$ crude protein. The fish were distributed in five different treatment groups of which the former and the latter had the lowest and the highest density of storage, respectively. Each treatment was replicated four times, as in first trial. The five stocking densities studied were: 10, 20, 30, 40 and $50 \mathrm{fish} / \mathrm{m}^{3}$ of water (TURRA et al. 2009). To obtain these densities we used 4, 8, 12, 16 and 20 fish per tank, respectively. The biomass of the animals in the tanks at the beginning of treatments corresponded to 1596.2, 3197.2, 4804.3, 6401.0 and $8023.5 \mathrm{~g}$, respectively.

\section{Blood samples and measurement of serum biochemical parameters}

At the end of the experiment two fish were taken randomly from each tank. Therefore, for each density eight repetitions were done, reaching a total of 40 animals in each trials. 
For the collection, quinaldine (Merck) at a concentration of $100 \mu \mathrm{l} / \mathrm{L}$ of water was used for anesthetic protocol. Blood samples were taken from each fish by puncturing the caudal vein using disposable-syringes, and immediately after the collection, $10 \mu \mathrm{l}$ of blood was used to measure glucose using a glucometer (Biocheck TD-4225 ${ }^{\circledR}$ - Bioeasy). Serum blood was collected after centrifugation ( $3500 \mathrm{X} \mathrm{g}$ for $5 \mathrm{~min}$ ) and stored at $-75^{\circ} \mathrm{C}$ as separate aliquots for analysis.

The concentration of serum total cholesterol, triglycerides, urea, creatinine, alkaline phosphatase (ALP), aspartate aminotransferase (AST), lactate dehydrogenase (LDH), calcium, phosphorus and magnesium were measured by spectrophotometer (TP Analyser basic ${ }^{\circledR}$ Thermo Plate) using commercial kits $\left(\right.$ Bioclin $^{\circledR)}$. The serum potassium concentration was determined by flame emission photometry.

\section{Statistical analysis}

The experimental design was completely randomized. The results were tabulated and analyzed by the computer program SAS (Statistical Analysis System) and SAEG (Sistema para Análises Estatísticas e Genéticas). Tests of normality (Lillifors) and homoscedasticity (Cochran and Bartlleti) were performed. The variables that were normally distributed (some of them after logarithmic transformation) were subjected to analysis of variance (ANOVA) and comparisons of means were made by the Tukey test $(\mathrm{p}<0.05)$.

The non-parametric variables were analyzed using the Kruskal-Wallis test. The variables on the different stocking densities used in both trials were measured by regression models. However, it did not fit the linear, quadratic and nor the cubic model.

\section{Ethics in animal experimentation}

The research project was approved by the Ethics Committee for Animal Experimentation (CETEA) of UFMG, with the protocol number 88/2008.

\section{RESULTS AND DISCUSSION}

\section{Growth and survival}

Daily weight gain showed reduction with the increase of the density in the first trial. However the Surubim hybrid presented proper growth and adaptation with the water recirculating system in the evaluated stocking densities. It was demonstrated by survival rate that was higher than $92 \%$ in the first trial (Table 1).

Differently from first trial, in second trial, the final weight and daily weight gain were not influenced by the density, except in density $50 \mathrm{fish} / \mathrm{m} 3$. It was demonstrated by survival rate that was $100 \%$ in the second trial (Table 2). However, final biomass presented direct relationship with increase density in all trials.

The different stocking densities were not a factor that could alter the concentration of serum glucose of Surubim hybrid (Pseudoplatystoma spp.) in all trials (Table 3 and 4). The blood glucose level is used in the research of fish farming as an efficient indicator of stress, since glucose is the main source of energy used by fish to withstand unfavorable conditions (KUBOKAWA et al., 1999; BRANDÃO et al., 2005). It is known that the detection of stressors may result, among other changes, in the stimulus for the release of catecholamines (adrenaline and noradrenaline) by chromaffin cells of fish body. Catecholamines stimulate glycogenolysis, causing the release of hepatic glucose, the main carbohydrate reserve

Table 1 - Initial average weight (g), final average weight $(\mathrm{g})$ and daily average weight gain (g); final biomass (g), biomass gain (g), feed conversion and survival rate (\%), followed by standard deviations of Surubim hybrid, Pseudoplatystoma reticulatum X P. corruscans, initial average weight of $147.6 \pm 2.1 \mathrm{~g}$, raised at five stocking densities $\left(\mathrm{fish} / \mathrm{m}^{3}\right)-$ first trial.

\begin{tabular}{cccccc}
\hline & & \multicolumn{5}{c}{ Stocking densities } \\
& $27.5 \mathrm{fish} / \mathrm{m}^{3}$ & $47.5 \mathrm{fish} / \mathrm{m}^{3}$ & $67.5 \mathrm{fish} / \mathrm{m}^{3}$ & $87.5 \mathrm{fish} / \mathrm{m}^{3}$ & $107.5 \mathrm{fish} / \mathrm{m}^{3}$ \\
\hline Initial weight & $147.5 \pm 2.6$ & $146.1 \pm 1.2$ & $147.4 \pm 3.0$ & $149.5 \pm 0.6$ & $147.2 \pm 2.1$ \\
Final weight & $520.7 \pm 24.0$ & $429.7 \pm 56.2$ & $370.6 \pm 35.9$ & $354.3 \pm 24.2$ & $343.0 \pm 16.2$ \\
Daily weight gain & $5.6 \pm 1.1$ & $4.2 \pm 0.7$ & $3.5 \pm 0.7$ & $3.3 \pm 0.2$ & $2.9 \pm 0.2$ \\
Final biomass & $5728.3 \pm 263.9$ & $8164.5 \pm 1067.4$ & $10008.7 \pm 969.4$ & $12399.5 \pm 845.7$ & $14750.3 \pm 698.0$ \\
Biomass gain & $4105.1 \pm 268.4$ & $5388.1 \pm 1073.3$ & $6027.1 \pm 1037.3$ & $7168.0 \pm 831.1$ & $8421.3 \pm 692.0$ \\
Feed conversion & $1.45 \pm 0.10$ & $1.48 \pm 0.28$ & $1.54 \pm 0.21$ & $1.51 \pm 0.04$ & $1.42 \pm 0.04$ \\
Survival rate & 100 & 100 & $95.3 \pm 7.0$ & $92.1 \pm 8.5$ & $97.7 \pm 1.9$ \\
\hline
\end{tabular}


of the fish. However, corticosteroids may contribute to the maintenance of hyperglycemia by gluconeogenesis from amino acids. Hyperglycemia related with stress is reported in several teleosts (BARCELLOS; SOUZA; WOETH, 2000), and there is also evidence of the involvement of catecholamines in the mobilization of free fatty acids, important energy sources for fish (VAN DER BOON et al., 1991).

Diploid and triploid all-female Atlantic salmon (Salmo salar) smolts were challenged with $2.5 \mathrm{~h}$ of confinement stress in aerated seawater and subsequent response was quantified by plasma glucose. The increase in plasma glucose with handling and confinement stress of both diploid and triploid fish indicated a typical salmonid response. This response is an important metabolic indicator of available energy reserves, and healthy rainbow trout may show elevated plasma for up to $24 \mathrm{~h}$ post-stress (SADLER et al., 2000). Fagundes and Urbinati (2008) evaluated the physiological response of juvenile Surubim (P. corruscans) created in renewal system of water while

Table 2 - Initial average weight (g), final average weight (g) and daily average weight gain (g); final biomass (g), biomass gain (g), feed conversion and survival rate (\%), followed by standard deviations of Surubim hybrid, Pseudoplatystoma reticulatum X P. corruscans, initial average weight of $400,0 \pm 1,4 \mathrm{~g}$, raised at five stocking densities (fish $\left./ \mathrm{m}^{3}\right)-$ second trial.

\begin{tabular}{|c|c|c|c|c|c|}
\hline & \multicolumn{5}{|c|}{ Stocking densities } \\
\hline & $10 \mathrm{fish} / \mathrm{m} 3$ & $20 \mathrm{fish} / \mathrm{m} 3$ & $30 \mathrm{fish} / \mathrm{m} 3$ & $40 \mathrm{fish} / \mathrm{m} 3$ & $50 \mathrm{fish} / \mathrm{m} 3$ \\
\hline Initial weight & $399.1 \pm 1.2$ & $399.6 \pm 1.9$ & $400.3 \pm 0.2$ & $400.1 \pm 0.3$ & $401.2 \pm 21.7$ \\
\hline Final weight & $961.9 \pm 153.1$ & $892.1 \pm 89.7$ & $914.3 \pm 11.2$ & $789.3 \pm 19.7$ & $589.5 \pm 79.4$ \\
\hline Daily weight gain & $7.8 \pm 2.1$ & $6.8 \pm 1.2$ & $7.1 \pm 0.2$ & $5.4 \pm 0.3$ & $2.6 \pm 1.1$ \\
\hline Final biomass & $3847.7 \pm 612.5$ & $7136.7 \pm 717.3$ & $10971.7 \pm 134.6$ & $12629.0 \pm 316.2$ & $11790.0 \pm 1587.7$ \\
\hline Biomass gain & $2251.5 \pm 613.8$ & $3939.5 \pm 713.0$ & $6167.6 \pm 135.9$ & $6230.0 \pm 316.2$ & $3766.5 \pm 1574.8$ \\
\hline Feed conversion & $1.2 \pm 0.2$ & $1.3 \pm 0.3$ & $1.4 \pm 0.1$ & $1.5 \pm 0.1$ & $1.8 \pm 0.1$ \\
\hline Survival rate & 100 & 100 & 100 & 100 & 100 \\
\hline
\end{tabular}

Table 3 - Mean values of glucose, cholesterol, triglycerides, urea, creatinine, ALP, AST, LDH, calcium, phosphorus and potassium followed by standard deviations of Surubim hybrid, Pseudoplatystoma reticulatum X P. corruscans $(\mathrm{n}=8)$, initial average weight of $147.6 \pm 2.1 \mathrm{~g}$, raised at five stocking densities $\left(\right.$ fish $\left./ \mathrm{m}^{3}\right)-$ first trial.

\begin{tabular}{|c|c|c|c|c|c|}
\hline & \multicolumn{5}{|l|}{ Stocking densities } \\
\hline & $10 \mathrm{fish} / \mathrm{m}^{3}$ & $20 \mathrm{fish} / \mathrm{m}^{3}$ & $30 \mathrm{fish} / \mathrm{m}^{3}$ & $40 \mathrm{fish} / \mathrm{m}^{3}$ & $50 \mathrm{fish} / \mathrm{m}^{3}$ \\
\hline Glucose $*(\mathrm{mg} / \mathrm{dl})$ & $85.76 \pm 15.56$ & $81.62 \pm 16.03$ & $84.87 \pm 9.86$ & $95.11 \pm 22.14$ & $101.00 \pm 48.91$ \\
\hline Cholesterol* (mg/dl) & $149.97 \pm 32.90$ & $137.45 \pm 38.03$ & $147.05 \pm 33.85$ & $155.36 \pm 29.01$ & $139.29 \pm 25.79$ \\
\hline Triglycerides* (mg/dl) & $208.94 \pm 139.85$ & $186.28 \pm 128.41$ & $142.08 \pm 52.19$ & $109.25 \pm 45.55$ & $133.28 \pm 59.10$ \\
\hline Urea** $\left.^{* *} \mathrm{mg} / \mathrm{dl}\right)$ & $12.58 \pm 2.89 \mathrm{a}$ & $15.71 \pm 4.10 \mathrm{ab}$ & $16.7 \pm 3.43 \mathrm{ab}$ & $17.26 \pm 2.53 b$ & $14.88 \pm 2.98 \mathrm{ab}$ \\
\hline Creatinine* $(\mathrm{mg} / \mathrm{dl})$ & $0.76 \pm 0.23$ & $0.46 \pm 0.24$ & $0.50 \pm 0.13$ & $0.44 \pm 0.21$ & $0.46 \pm 0.23$ \\
\hline ALP* & $36.81 \pm 13.78$ & $48.23 \pm 12.90$ & $38.66 \pm 23.79$ & $34.28 \pm 12.14$ & $33.24 \pm 10.32$ \\
\hline $\mathrm{AST}^{*}$ & $42.47 \pm 19.70$ & $35.49 \pm 11.44$ & $38.19 \pm 8.52$ & $35.68 \pm 6.03$ & $38.42 \pm 7.03$ \\
\hline $\mathrm{LDH}^{*} \quad(\mathrm{U} / \mathrm{l})$ & $44.58 \pm 6.21$ & $43.36 \pm 10.40$ & $41.37 \pm 7.42$ & $46.43 \pm 13.45$ & $50.40 \pm 18.30$ \\
\hline Calcium* (mg/dl) & $12.61 \pm 1.87$ & $11.84 \pm 2.27$ & $11.13 \pm 2.45$ & $12.02 \pm 3.04$ & $11.74 \pm 2.36$ \\
\hline Phosphorus** (mg/dl) & $12.47 \pm 2.11$ & $12.28 \pm 4.12$ & $13.87 \pm 2.04$ & $13.07 \pm 1.96$ & $14.43 \pm 1.56$ \\
\hline Potassium** (mmol/l) & $3.65 \pm 1.32$ & $3.50 \pm 1.09$ & $3.99 \pm 1.01$ & $3.79 \pm 1.50$ & $3.59 \pm 1.15$ \\
\hline
\end{tabular}

Means followed by different letters differ statistically between groups (stocking density), submitted to ANOVA, and Tukey's test* or Kruskal-Wallis test**, $\mathrm{P}<0.05$.

Ciênc. agrotec., Lavras, v. 37, n. 3, p. 251-258, maio/jun., 2013 


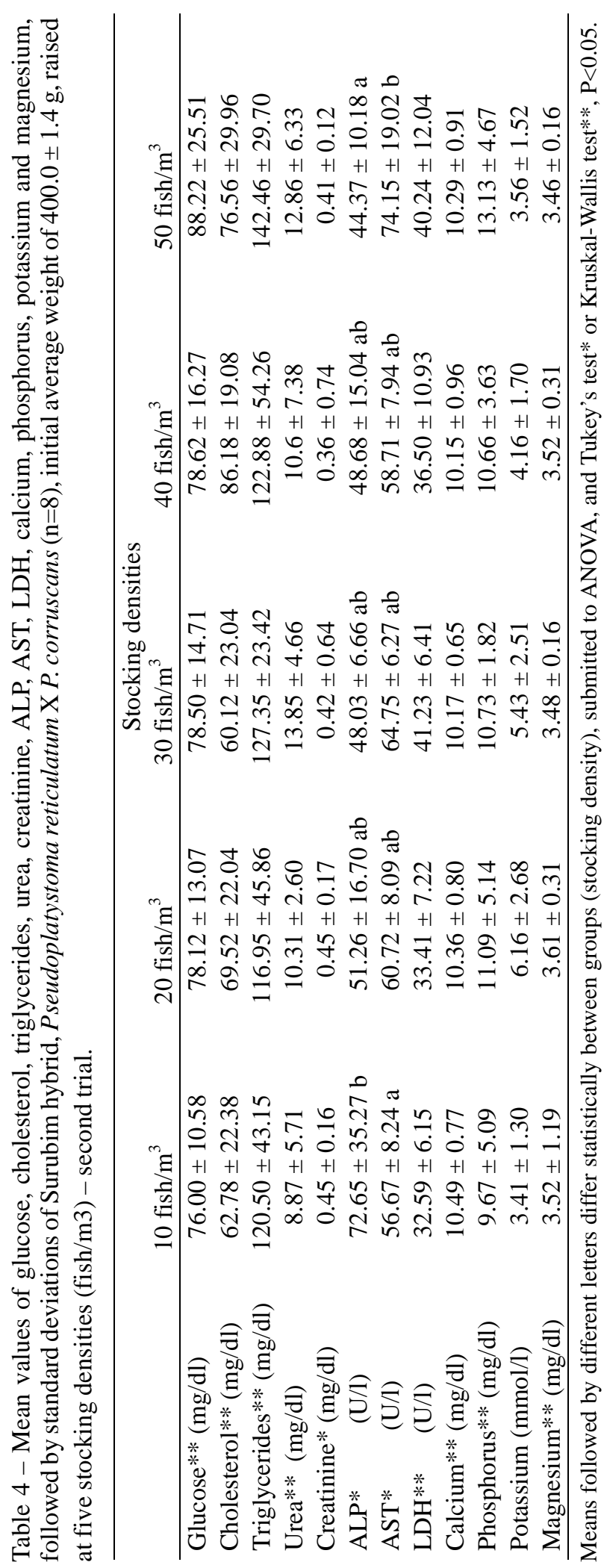

the fish were exposed to three usual stressors in raising fish (capture, transport and light). The researchers reported that in the capture, there were increased levels of plasma glucose in the Surubim. However, during transport, there was a decrease in blood glucose levels. During exposure to light, there were no significant differences in blood glucose levels.

In first trial, the mean cholesterol values ranged from 137.45 to $155.36 \mathrm{mg} / \mathrm{dl}$ and triglycerides from 109.25 to $208.94 \mathrm{mg} / \mathrm{dl}$ (Table 3). In second trial (Table 4), the mean cholesterol values ranged from 60.12 to $86.18 \mathrm{mg} / \mathrm{dl}$ and triglycerides from 116.95 to $142.46 \mathrm{mg} / \mathrm{dl}$. Cholesterol and triglycerides are lipids that appear in the blood connected to proteins, forming a complex called lipoprotein. Cholesterol is mainly synthesized in the liver, which plays an important role not only in the synthesis, but also in the catabolism and excretion of this lipid. Cholesterol is used in the synthesis of steroid hormones and as a component of cell membranes. The concentration of cholesterol in the blood can be influenced by the nutrition, the activity level, the hepatic activity, and can be changed by the sexual cycle of fish. Triglycerides are the major lipids of the adipose tissue and it is the most important form of fat storage in the body. The concentration of triglycerides in the blood is influenced by the fat content in the diet, being, therefore, an important blood component to be evaluated in the use of new diets (VAN DER BOON et al., 1991). In all trials, the different densities no exerted an influence on cholesterol and triglycerides indices.

In first trial, the urea values ranged $(\mathrm{P}<0.05)$ from $12.58\left(10 \mathrm{fish} / \mathrm{m}^{3}\right)$ to $17.26 \mathrm{mg} / \mathrm{dl}\left(40 \mathrm{fish} / \mathrm{m}^{3}\right.$ ) (Table 1 ) and the creatinine values ranged from $0.44\left(40 \mathrm{fish} / \mathrm{m}^{3}\right)$ to 0.76 $\mathrm{mg} / \mathrm{dl}\left(10 \mathrm{fish} / \mathrm{m}^{3}\right)$. In second trial, there was no difference between the density in both urea and creatinine values (Table 4). Thrall et al. (2004) stipulated that the concentration of urea in freshwater teleosts must not exceed $10 \mathrm{mg} / \mathrm{dl}$. However, the averages of all groups in both trials (except in the second trial of the $10 \mathrm{fish} / \mathrm{m}^{3}$ density) were above this value.

The caudal portion of the kidney is primarily responsible for urinary activity in fish. As this organ does not contribute significantly to the excretion of nitrogenous waste, the assessment of the concentration of urea and creatinine may not have a relevant clinical significance in the evaluation of renal diseases. In several species of fish, the gills appear to have more responsibility in the excretion of ammonia than the kidneys. Hence, the increase in these variables in fish may be indicative of a change in the gill epithelium (SHIH et al., 2008). According to Thrall et al. (2004), creatinine values in teleosts vary from 0.5 to 2.0 
$\mathrm{mg} / \mathrm{dl}$. The creatinine concentrations observed in both trials are slightly below the lower limit of the range proposed by this author, except for the density $27.5 \mathrm{fish} / \mathrm{m}^{3}(0.76 \mathrm{mg} / \mathrm{dl})$ and density $67.5 \mathrm{fish} / \mathrm{m}^{3}(0.50 \mathrm{mg} / \mathrm{dl})$ in first trial. Although surubins are classified as teleost fish, serum urea and creatinine values from fish used in both trials are new among the literature results. Creatinine is the end product of energy used by muscle tissue. This is formed from creatine, and its blood concentration can be changed on different levels of muscle activity (THRALL et al., 2004).

In first trial, there was no statistical difference ( $\mathrm{P}$ > 0.05 ) between groups for the values of alkaline phosphatase (ALP), aspartate aminotransferase (AST) and lactate dehydrogenase (LDH) (Table 3). In second trial, the lowest and highest concentrations observed were 44.37 (50 fish/ $\mathrm{m} 3)$ and $72.65 \mathrm{U} / \mathrm{l}$ of ALP $\left(10 \mathrm{fish} / \mathrm{m}^{3}\right)$, respectively. These densities $(10$ and 50 fish $/ \mathrm{m} 3)$ differed $(\mathrm{P}<0.05)$ for both the ALP and AST values (Table 4).

The ALP is a lysosomal enzyme present in cells from various tissues, especially in the liver and bone cells (osteoblasts), which participates in the skeleton mineralization of the aquatic animals, and performs membrane transport activities. The increase of ALP concentrations in blood may result from increased osteoblastic activity, cholestasis and chronic disease. It is believed that the highest values $(\mathrm{P}<0.05)$ of ALP in 10 fish $/ \mathrm{m}^{3}$ density (second trial) could be a result from increased fish growth rate, since in both trials the animals raised at lower densities gained more weight daily (Tables 1 and 2).

In first trial, it was observed lower concentration of AST (56.67 U/l) in the $27.5 \mathrm{fish} / \mathrm{m}^{3}$ density, and higher concentration in the $107.5 \mathrm{fish} / \mathrm{m} 3$ density ( $74.15 \mathrm{U} / \mathrm{l})$. In second trial, the animals stored in the highest density $\left(107.5 \mathrm{fish} / \mathrm{m}^{3}\right)$ presented an AST statistically different than the ones from $27.5 \mathrm{fish} / \mathrm{m}^{3}$ density. However, it is believed that these results are due to a discrete muscle damage resulted from the high number of animals stocked in each tank, and not because of liver injury, since the mean value of ALP was the lowest observed in the highest density.

In both trials, our results of AST and ALP differed from Lenhardt et al., (1992) that studied the natural population of pike (Esox lucius L.) from the River Danube during 12 month to determine seasonal variations in biochemical parameters of blood sera. The ranges of enzyme activities for sample means were: aspartate aminotransferase (AST) 252.0-583.8 UL"1 and alkaline phosphatase (ALP) 39.5-91.8 UL"1. AST is not a liverspecific enzyme and, therefore, it may be present both in hepatocytes and muscle cells, kidneys, and also may be present in the gills. It is commonly used to assess the liver, as hepatocellular diseases can result in increased serum AST (HEGAZI et al., 2010).

In second trial, the enzyme LDH showed values ranging from 32.59 to $41.23 \mathrm{U} / \mathrm{l}$ in $10 \mathrm{fish} / \mathrm{m} 3$ and $30 \mathrm{fish} / \mathrm{m} 3$ densities, respectively (Table 2). LDH is present in the cytoplasm of different cells of the body. However, an increase in the bloodstream can be related to liver or muscle damage (COZ-RAKOVAC et al., 2005).

Serum calcium, phosphorus and potassium showed no statistical differences between groups (stocking densities) in first trial (Table 3). Likewise, in second trial there was no difference between groups $(\mathrm{P}>0.05)$ for the values of calcium, phosphorus, potassium and magnesium (Table 4). The blood concentration of calcium can be influenced by the calcium content in the environment. Its transportation is performed by gill cells and its regulation is done by the stanniocalcina hormone that acts as a calcium channel blocker, in order to avoid hypercalcemia. It is also important to consider that calcium levels vary along with the total plasma protein and, in humans, with blood $\mathrm{pH}$, as this influences the binding of calcium to albumin (ENDRES; RUDE, 1999). The values of calcium, phosphorus and potassium in this study are similar to those observed in the literature for other fish species. In Piaractus brachypomus, calcium concentration was $10.80 \mathrm{mg} / \mathrm{dl}$, phosphorus $7.29 \mathrm{mg} / \mathrm{dl}$ and potassium was $3.93 \mathrm{mmol} / \mathrm{l}$ (SAKAMOTO; LEWBART; SMITH, 2001). JIØÍ-Øehulka and Minaøík (2008) evaluated total calcium and inorganic phosphate in the blood plasma of farmed rainbow trout (Oncorhynchus mykiss) at an age of 10-12 months in raceway culture. Total calcium levels were significantly (Pd"0.0009) greater in males (2.63-4 mmol/l, mean weight $359 \pm 142 \mathrm{~g})$ than in immature females $(2.48-3.97 \mathrm{mmol} / \mathrm{l}$, mean weight $400 \pm 145 \mathrm{~g}$ ). The reference range for $\mathrm{P}$ in immature females and males was 3.09-9.32 mmol/1 (mean weight $401 \pm 144 \mathrm{~g}$ ). Chen, Wooster and Bowser (2004) found $3.56 \mathrm{mmol} / 1$ of potassium studying Oreochromis niloticus.

Factors such as stress can cause changes in the values of these minerals. It was also observed that infection with Streptococcus iniae in Oreochromis niloticus was able to increase potassium levels in the blood and decrease the levels of calcium and magnesium (CHEN; WOOSTER; BOWSER, 2004). In both trials, the levels of calcium, phosphorus and potassium show that different densities cannot influence these components in Pseudoplatystoma spp. 


\section{CONCLUSIONS}

The few changes showed by the variables studied in the blood biochemical profile do not characterize the loss of homeostasis in fish, demonstrating that the Surubim hybrid health remained independent of the stocking density in which they have been cultivated.

\section{ACKNOWLEDGMENT}

This study was funded by FAPEMIG.

\section{REFERENCE}

BARCELLOS, L.J.G. et al. Hematological changes in jundiá (Rhamdia quelen Quoy and Gaimard Pimelodidae) after acute and chronic stress caused by usual aquacultural management, with emphasis on immunosuppressive effects. Aquaculture, Amsterdan, v.237, n.1-4, p.229-236, aug, 2004.

\section{BARCELLOS, L.J.G., SOUZA, S.M.G., WOEHT, V.M.} Estresse em peixes: fisiologia da resposta ao estresse, causas e consequências (revisão). Boletim do Instituto de Pesca, São Paulo, v.26, n.1, p.99-111, mar, 2000.

BRANDÃO, F.R. et al. Densidade de estocagem de matrinxã (Brycon amazonicus). Pesquisa Agropecuária Brasileira, Brasília, v.40, n.3, p. 299-303, mar, 2005.

CARVALHO, D.C. et al. Identificação molecular de peixes: o caso do Surubim (Pseudoplatystoma spp.). Revista Brasileira de Reprodução Animal, Belo Horizonte, v.32, n.4, p.215-219, out./dez, 2008.

CHEN, C.; WOOSTER, G.A.; BOWSER, P.R. Comparative blood chemistry and histopathology of tilapia infected with Vibrio vulnificus or Streptococcus iniae or exposed to carbontetrachloride, gentamicin, or copper sulfate. Aquaculture, Amsterdan, v.239, n.1-4, p.421-443, sep, 2004.

CNAANI, A. et al. Comparative study of biochemical parameters in response to stress in Oreochromis aureus, $O$. mossambicus and two strains of $O$. niloticus. Aquaculture Research, Stirling, v.35, n.15, p.1434-1440, dec, 2004.

COZ-RAKOVAC, R. et al. Blood chemistry and histological properties of wild and cultured sea bass (Dicentrarchus labrax) in the north Adriatic sea. Veterinary Research Communication, Edinburgh, v.29, n.8, p.677-687, nov, 2005.
ELLIS, T. et al. The relationships between stocking density and welfare in farmed rainbow trout. Journal of Fish Biology, Dunscore, v.61, n.3, p.493-531, sep, 2002.

ENDRES, D.B.; RUDE, R.K. Mineral and bone metabolism. In: SAUNDERS,W.B. Tietz textbook of clinical chemistry. Philadelphia, USA: W.B. Saunders, 1999, p.1395-1457.

FAGUNDES, M.; URBINATI, E.C. Stress in pintado (Pseudoplatystoma corruscans) during farming procedures. Aquaculture, Amsterdan, v.276, n.1-4, p.112-119, April, 2008.

FARIA, P.M.C. et al. Produção do híbrido "cachadia" em diferentes densidades de estocagem em sistema de recirculação de água. Arquivo Brasileiro de Medicina Veterinária e Zootecnia, Belo Horizonte, v.63, n.5, p.1208-1214, out, 2011.

HEGASI, M.M. et al. Metabolic consequences of chronic sublethal ammonia exposure at cellular and subcellular levels in Nile tilapia brain. Aquaculture, Amsterdan, v.299, p.149-156, feb, 2010.

JIØÍ-ØEHULKA, J.; MINAØÍK, B. Total calcium and inorganic phosphate in the blood plasma of farmed rainbow trout, Oncorhynchus mykiss. Aquaculture Research, Stirling, v.39, n.11, p.1161-1168, augt, 2008.

KUBOKAWA, K. et al. Effects of acute stress on plasma cortisol, sex steroid hormone and glucose levels in male and female sockeye salmon during the breeding season. Aquaculture, Amsterdan, v.172, n.3-4, p.335-349, mar, 1999.

LENHARDT, M. Seasonal changes in some blood chemistry parameters and in relative liver and gonad weights of pike (Esox lucius L.) from the River Danube. Journal of Fish Biology, Dunscore, v.40, n.5, p.709-718, may, 1992.

LIMA, L.C. et al. Effects of temperature on performance characteristics and the cortisol stress response of Surubim Pseudoplatystoma sp. Journal of the World Aquaculture Society, Frankfort, v.37, n.1, p.89-95, mar, 2006.

MARCO P.D. et al. Physiological responses of European sea bass Dicentrarchus labrax to different stocking densities and acute stress challenge. Aquaculture, Amsterdan, v.275, n.1-4, p.319-328, mar, 2008. 
PRADO, F.D. et al. Cytogenetic characterization of F1, F2 and backcross hybrids of the Neotropical catfish species Pseudoplatystoma corruscans and Pseudoplatystoma reticulatum (Pimelodidae, Siluriformes). Genetics and Molecular Biology, São Paulo, v.35, n.1, p.57-64, fev, 2012.

SADLER, J. et al. Blood oxygen, transport, rheology and haematological responses to confinement stress in diploid and triploid Atlantic salmon, Salmo salar. Aquaculture, Amsterdan, v.184, n.3-4, p.349-361, apr, 2000.

SAKAMOTO, K., LEWBART, G.A., SMITH, T.M. Blood chemistry value of juvenile Red Pacu (Piaractus

brachypomus). Veterinary Clinical Pathology, Madison, v.30, n.2, p.50-52, jun, 2001.

SCHRAM, E. et al. Stocking density-dependent growth of Dover sole (Solea solea), Aquaculture, Amsterdan, v.252, n.2-4, p.339-347, marc, 2006.

SHIH, T.H. et al. Ammonia excretion by the skin of Zebrafish (Danio rerio) larvae. American Journal of
Physiology - Cell Physiology, Bethesda, v.295, n.6, p.1625-1632, dec, 2008.

THRALL, M.A et al. Clinical Chemistry of Fish and Amphibians. Veterinary Hematology and Clinical Chemistry. Philadelphia: Lippincott Williams \& Wilkins, 2004, p.499-504.

TURRA, E.M. et al. Densidade de estocagem do surubim Pseudoplatystoma spp. cultivado em tanque-rede. Revista Brasileira de Saúde e Produção Animal, Salvador, v.10, n.1, p.177-187, jan/mar, 2009.

VAN DER BOON, J.; VAN DEN TRILLART, GE.E.J.M.; ADDINK, A.D.E. The effect of cortisol administration on intermediary metabolism in teleost fish. Comparative Biochemistry and Physiology, Victoria, v.100, n.1, p.4753, apr, 1991.

VAN DE NIEUWEGIESSEN et al. Assessing the effects of a chronic stressor, stocking density, on welfare indicators of juvenile African catfish, Clarias gariepinus Burchell. Applied Animal Behaviour Science, Philadelphia, v.115, n.3/4, p. 233-243, dec, 2008.

Ciênc. agrotec., Lavras, v. 37, n. 3, p. 251-258, maio/jun., 2013 